\title{
Comparative study between propofol and propofol-ketamine for induction of anesthesia in dogs
}

\author{
Estudo comparativo entre propofol e propofol-cetamina para a indução anestésica em \\ cães
}

\author{
Daniela Santilli CIMA ${ }^{1}$; Keiji SATO²; Jacqueline Silva TORRECILLA²; Vinicius Toshio IWATA²; Fábio \\ FUTEMA $^{1,2}$
}

\author{
${ }^{1}$ Universidade Guarulhos, Guarulhos - SP, Brazil \\ ${ }^{2}$ Universidade Paulista, São Paulo - SP, Brazil
}

\begin{abstract}
Anesthetic procedures in animals are widely used in hospital for routine surgery. For induction of anesthesia in dogs, propofol has been shown to be the drug of choice. The objectives of this study were the assessment of induction of anesthesia using propofol or propofol-ketamine. Twenty client-owned dogs were randomly assigned to treatment and control groups. All patients were administered acepromazine $(0.05 \mathrm{mg} \mathrm{kg}-1)$ and fentanyl $(5 \mu \mathrm{g} \mathrm{kg}-1)$ for premedication by intramuscular (IM) injection. Dogs in the treatment group were administered ketamine (1 mg kg-1), while dogs in the control group were administered $0.9 \%$ saline solution, by intravenous (IV) injection. Induction of anesthesia was done using IV propofol at a rate of $1 \mathrm{~mL}$ minute-1. Cardiopulmonary patterns were assessed before application of premedication, 15 minutes after application of premedication and after induction of anesthesia with propofol. Additionally, data regarding tracheal intubation score, presence of adverse effects and dose of propofol necessary for induction of anesthesia were collected. The control group showed significantly more adverse effects and changes in cardiopulmonary patterns when compared to the treatment group. There was a clinically significant reduction in the dose of propofol necessary for induction of anesthesia when associated with ketamine. The association of ketamine for induction of anesthesia in healthy dogs using propofol was able to reduce the dose of the induction agent necessary for tracheal intubation. Moreover, there was a reduction in the occurrence of adverse effects and cardiopulmonary depression, which allowed for a safer procedure for the patients.
\end{abstract}

Keywords: Anesthesia. Dog. Induction. Ketamine. Propofol.

\section{Resumo}

Os procedimentos anestésicos em animais são amplamente utilizados em hospitais para cirurgias de rotina. Para a indução anestésica em cães o propofol tem se mostrado o fármaco de escolha. O objetivo deste estudo foi a avaliação da indução anestésica com propofol ou propofol-cetamina. Vinte cães foram divididos de forma aleatória nos grupos com tratamento e controle. Em todos os pacientes administrou-se acepromazina $(0,05 \mathrm{mg} \mathrm{kg}-1)$ e fentanil $(5 \mu \mathrm{g} \mathrm{kg}-1)$ como medicação préanestésica por via intramuscular (IM). Nos cães do grupo de tratamento foi administrado cetamina (1 mg kg-1), enquanto que os cães do grupo controle receberam solução salina a $0,9 \%$, pela via intravenosa (IV). A indução da anestesia foi realizada com propofol IV a uma taxa de $1 \mathrm{~mL}$ minuto-1. Os padrões cardiopulmonares foram avaliados antes da aplicação da medicação préanestésica, 15 minutos após a mesma e após a indução da anestesia. Além disso, avaliou-se o escore de intubação traqueal, a presença de efeitos adversos e a dose de propofol necessária para a indução da anestesia. De forma significativa, o grupo controle apresentou mais efeitos adversos e alterações nos padrões cardiopulmonares quando comparado com o grupo de tratamento. Houve uma redução clinicamente importante da dose de propofol necessária para a indução de anesthesia quando associado à cetamina. A associação de cetamina ao propofol para indução de anestesia em cães saudáveis foi capaz de reduzir a dose do anestésico geral necessária para intubação traqueal. Além disso, houve uma redução na ocorrência de efeitos adversos e depressão cardiopulmonar, o que permitiu um procedimento mais seguro para os pacientes.

Palavras-chave: Anestesia. Cão. Indução. Cetamina. Propofol. 
Correspondence to:

Daniela Santilli Cima

Universidade Guarulhos

Av. Anton Philips, 01, Vila Hermínia

CEP 07030-010, Guarulhos, SP, Brazil

e-mail: dsantilli3@gmail.com

Received: $12 / 12 / 2014$

Approved: 06/04/2016

\section{Introduction}

Anesthesia is frequently used for surgical interventions in animals, with the objective of promoting analgesia and producing an adequate anesthetic plane for the procedure in question, with as little systemic alterations as possible. In order to achieve this objective, there are a number of anesthetic agents and associations available for use in veterinary medicine. Among those is propofol, a drug widely used in small animal anesthesia, which may be associated with different drugs, such as ketamine, in order to reduce adverse effects of the agents used.

Propofol has been the drug of choice for induction of anesthesia in dogs, due to its short latency (ANDREONI; LYNNE HUGHES, 2009), fast induction and adequate anesthetic planes. Additionally, it has a short duration of action, fast elimination, and smooth recovery. Nevertheless, it has some adverse effects, such as reduction of arterial blood pressure, apnea, hypoventilation (SMITH et al., 1993), and excitation (DAVIES, 1991), which are dosedependent. Therefore, its association with other anesthetic agents, which allow reduction of its dose, is beneficial (LERCHE et al., 2000; INTELISANO et al., 2008).

The hypnotic and anesthetic effects of ketamine occur via $N$-methyl-D-aspartate (NMDA) receptors (MAYER; MILLER, 1990). It is a dissociative anesthetic with analgesic effects, which should be used in association with other drugs due to its possible adverse effects, such as cardiovascular stimulation, catalepsy, and agitated recovery (WRIGHT, 1982; HASKINS et al., 1985). Association of ketamine and propofol may reduce unwanted adverse effects of both drugs, since these drugs act on different extremes excitation and depression, respectively (MAIR et al., 2009).

In human anesthesia, the association of ketamine and propofol led to a reduction of the dose of propofol necessary for induction (SRIVASTAVA et al., 2006). Consequently, hemodynamic and respiratory adverse effects where attenuated, when compared to use of propofol alone (FURUYA et al., 2001; SRIVASTAVA et al., 2006). Another advantage of using low-dose ketamine is reduction of post-operative pain (ROYTBLAT et al., 1993).

The objective of the present study was to assess and compare the quality of induction produced by propofol or the association propofol-ketamine, as well as the possible reduction in the dose of propofol when associated with ketamine. Animals were monitored during the procedure to assess cardiopulmonary changes, quality of endotracheal intubation, and adverse effects produced by each anesthetic protocol.

\section{Material and Methods}

The study was designed as a prospective, randomized double-blinded placebo-controlled clinical trial. It was approved by the Institutional Animal Care and Use Committee (Protocol number 145/13 CEP/ICS/UNIP), and had the owners' spoken and written consent.

Twenty client-owned dogs were used, regardless of breed or sex, all of which were classified as ASA (American Society of Anesthesiologists) physical status I or II. Dogs were scheduled for elective surgery or other procedures that required general anesthesia. All patients were subjected to pre-anesthetic evaluation in which body condition score (BCS) was assessed using a scale from 1 through 9, were 1 is cachectic and 9 is obese (LAFLAMME, 1997; MAWBY et al., 2001). Animals considered either underweight (BCS 1-3) or overweight (BCS 7-9) were excluded from the trial. Prior to surgery dogs were withheld from food for 12 hours and from water for 4 hours. 
Dogs were randomly assigned to either the treatment group (ketamine-propofol, KP) or the control group (saline-propofol, P) by drawing lots. All patients were administered acepromazine $(0.05 \mathrm{mg} \mathrm{kg}$ ${ }^{1}$; acepromazin 0.2\%; Syntec, Hortolândia, SP, Brazil), and fentanyl $\left(5 \mu \mathrm{g} \mathrm{kg}^{-1}\right.$; fentanest $0.05 \mathrm{mg} \mathrm{mL}$; Cristália, Itapira, SP, Brazil) for premedication by intramuscular (IM) injection. After 15 minutes from premedication, vital parameters were assessed, followed by catheterization of the cephalic vein, using an appropriate catheter (Nipro, Sorocaba, SP, Brazil) according to animal size. An infusion of Ringer lactate solution (Equiplex, Aparecida de Gioânia, GO, Brazil) was started at a rate of $10 \mathrm{~mL} \mathrm{~kg}^{-1}$ hour $^{-1}$. The treatment group was administered ketamine ( $1 \mathrm{mg} \mathrm{kg}^{-1}$; Dopalen 10\%; Ceva, Paulínia, SP, Brazil), while the control group was administered an equivalent volume of 0.01 $\mathrm{ml} \mathrm{kg}-1$ of $0.9 \%$ saline solution, by intravenous (IV) injection.

Induction of anesthesia began $30 \mathrm{~min}$ after administration of premedication. The whole procedure was done by an anesthetist with no previous knowledge of the treatment protocol being used. For this, a syringe containing either ketamine or saline solution (both clear solutions) was presented to the anesthetist, who administered it through the IV catheter, immediately followed by propofol (Propotil 1\%; BioChimico, Rio de Janeiro, RJ, Brazil) infusion. Propofol was delivered by an isovolumetric infusion pump (DigiPump LP8X, Digicare Biomedical) at a rate of $1 \mathrm{~mL}$ minute $^{-1}$, until endotracheal intubation was possible. During induction, the patient was observed for muscle relaxation, and when it was completely relaxed, the anesthetist verified if there was loss of mandibular tonus and palpebral reflex. Intubation was possible when there was loss of these reflexes. A fixed infusion rate was used to guarantee the same speed of administration for every patient, since this could influence the appearance of adverse effects and the quality of induction.

The following variables were evaluated before administration of premedication, 15 minutes after administration of premedication, and immediately after induction of anesthesia heart rate (HR, beats minute $^{-1}$ ), systolic (SAP), diastolic (DAP) and mean (MAP) arterial blood pressure $(\mathrm{mmHg})$, and respiratory rate $\left(f_{\mathrm{R}}\right.$, breaths minute $\left.{ }^{-1}\right)$. Heart rate was obtained through cardiac auscultation of the left hemithorax, between the third and fifth intercostal space. Arterial blood pressure was obtained using the oscillometric method (Neovet 2009, Centaurus Medical LLC, USA). The cuff was placed on the midforeleg, and had a width equivalent to $40 \%$ of the patient's limb circumference. Respiratory rate was obtained by observation of respiratory movements.

Dogs were maintained in lateral recumbence during assessment of vital parameters. In addition, the quality of endotracheal intubation was assessed using a rating scale proposed by Covey-Crump and Murison (2008), where (0) indicates a smooth intubation (no swallowing, coughing, or tongue/jaw movement), (1) indicates a fair procedure (presence of discrete tongue movement and coughing), (2) indicates a poor procedure (presence of strong tongue/jaw movement, swallowing or coughing), and (3) indicates a very poor procedure (same as score 3 , but requiring additional propofol, and new attempt at intubation).

For statistical analyses, the study was divided into data analysis and statistical inference. For statistical inference, the methods used were Shapiro-Wilk test, Student's t-test, Wilcoxon test and the likelihood function. All analyses were performed using $\mathrm{R}$ software (Bell Laboratories, Lucent Technologies). A $p$ value $<0.05$ indicated statistically signifi $c$ a $n$ t $\quad r$ e $s$ u l t $s$.

\section{Results}

Patients were between one and fifteen years old, of various breeds, weighing from 3.9 to $55 \mathrm{~kg}$. Induction of anesthesia was effective in all patients and allowed for smooth tracheal intubation. Five animals showed post-induction apnea, of which three were from the $\mathrm{P}$ group, while two were from the KP group. Time to first spontaneous breath was $43.4 \%$ faster in the KP group when compared to the $\mathrm{P}$ group. Animals in the KP 
group took a mean of 2 min to first spontaneous breath, while animals in the P group took a mean of 4.6 minutes. The only dog that exhibited myoclonic twitching was from the $\mathrm{P}$ group.

Regarding intubation scores, for the P group 20\% of the animals were classified as score $0,70 \%$ as score 1 , and $10 \%$ as score 2 , while for the KP group, $40 \%$ were classified as score 0 and $60 \%$ as score 1 .

The mean dose of propofol required for induction was $3.4 \mathrm{mg} \mathrm{kg}^{-1}$ for the $\mathrm{P}$ group and $2.6 \mathrm{mg} \mathrm{kg}^{-1}$ for the
KP group, yielding a reduction of $23.6 \%$ in the dose of the induction agent necessary for intubation, when associated with ketamine.

As can be observed in the boxplot, data obtained for vital parameters exhibited a symmetrical characteristic in most cases. Nevertheless, when post-intubation parameters were compared between groups, there was greater asymmetry in the $\mathrm{P}$ group when compared to the KP group, for the $f_{R}, \mathrm{SAP}, \mathrm{MAP}, \mathrm{DAP}$, and HR (Figure 1).

$\mathbf{P}$

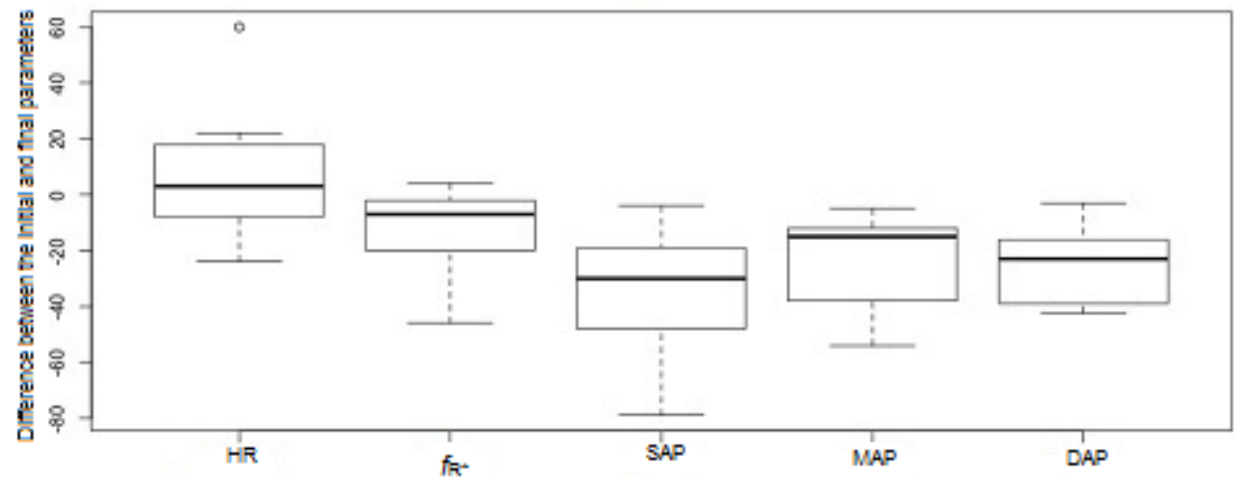

KP

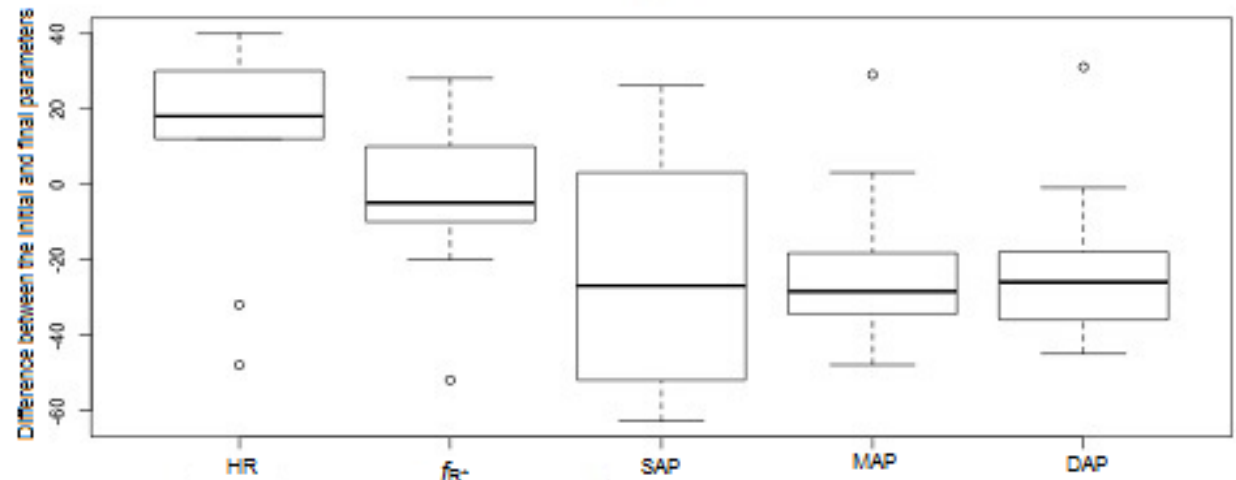

Figure 1 - Box-plot showing an analysis of the distribution of the samples before and after administration of propofol (group P, $n=10$ ) or ketamine-propofol (group KP, $n=10$ ) in dogs premedicated with acepromazine and fentanyl. Boxes represent the first and third quartiles, midlines represent the median, whiskers represent standard deviation and circles represent outliers. $\mathrm{HR}$, heart rate; $f_{\mathrm{R}}$, respiratory rate; $\mathrm{SAP}$, systolic arterial pressure; $\mathrm{MAP}$, mean arterial pressure; DAP, diastolic arterial pressure

According to the Shapiro-Wilk test, there was no statistical difference between groups regarding $\mathrm{HR}$ ( $p=$ $0.207), f_{\mathrm{R}}(p=0.314), \operatorname{SAP}(p=0.104), \operatorname{MAP}(p=0.705)$ and $\operatorname{DAP}(p=0.926)$ before administration of premedication. After 15 minutes of premedication, $\mathrm{HR}(p$ $=0.572), \operatorname{SAP}(p=0.925), \operatorname{MAP}(p=0.272)$ and DAP $(p=$ 0.712 ) variables were statistically similar, while the $f_{R}(p=$ 0.018 ) showed a difference between groups. Similarly, after 
induction of animals, HR $(p=0.189)$, SAP $(p=0.292)$, MAP $(p=0.409)$ and DAP $(p=0.0592)$ showed no statistical differences, while $f_{\mathrm{R}}$ ( $p=0.008$ ) was statistically different between groups (Table 1).

Table 1 - Cardiopulmonary variables (mean \pm SD) obtained from dogs before administration of premedication (baseline); 15 minutes after administration of acepromazine and fentanyl as premedication (post premedication) and immediately after administration of propofol (group P, $n=10$ ) or ketamine-propofol (group KP, $n=10$ ) (post induction) - São Paulo $-2013$

\begin{tabular}{|c|c|c|c|c|}
\hline Variable & Group & Baseline & Post premedication & Post induction \\
\hline \multirow{3}{*}{ HR (beats minute-1) } & \multirow{3}{*}{$\begin{array}{c}\mathrm{P} \\
\mathrm{KP}\end{array}$} & $100.7 \pm 25.35$ & $101.4 \pm 23.47$ & $107.6 \pm 33.26$ \\
\hline & & $88.8 \pm 31.81$ & $107.8 \pm 26.72$ & $118.4 \pm 13.02$ \\
\hline & & $(p=0.207)$ & $(\mathrm{p}=0.572)$ & $(p=0.189)$ \\
\hline \multirow{3}{*}{$\mathrm{SAP}(\mathrm{mmHg})$} & \multirow{3}{*}{$\begin{array}{c}\mathrm{P} \\
\mathrm{KP}\end{array}$} & $157.2 \pm 13.76$ & $136.73 \pm 17.48$ & $101.93 \pm 10.99$ \\
\hline & & $145.1 \pm 26.08$ & $126.31 \pm 23.27$ & $101.65 \pm 15.82$ \\
\hline & & $(p=0.104)$ & $(p=0.925)$ & $(p=0.292)$ \\
\hline \multirow{3}{*}{ MAP (mmHg) } & \multirow{3}{*}{$\begin{array}{c}\mathrm{P} \\
\mathrm{KP}\end{array}$} & $118.65 \pm 21.15$ & $96.36 \pm 15.39$ & $72.06 \pm 9.74$ \\
\hline & & $107.9 \pm 26.32$ & $91.03 \pm 17.19$ & $68.6 \pm 12.88$ \\
\hline & & $(p=0.705)$ & $(p=0.272)$ & $(p=0.409)$ \\
\hline \multirow{3}{*}{$\mathrm{DAP}(\mathrm{mmHg})$} & \multirow{3}{*}{$\begin{array}{c}\mathrm{P} \\
\mathrm{KP}\end{array}$} & $100.7 \pm 25.35$ & $77.66 \pm 11.27$ & $52.13 \pm 11.15$ \\
\hline & & $88.8 \pm 31.81$ & $75.3 \pm 16.61$ & $53.4 \pm 13.21$ \\
\hline & & $(p=0.926)$ & $(p=0.712)$ & $(p=0.0592)$ \\
\hline \multirow{3}{*}{$f_{\mathrm{R}}$ (breaths minute $\left.{ }^{-1}\right)$} & \multirow{3}{*}{$\begin{array}{c}\mathrm{P} \\
\mathrm{KP}\end{array}$} & $34.2 \pm 10.08$ & $26.2 \pm 11.79$ & $14.6 \pm 8.59$ \\
\hline & & $37.4 \pm 9.14$ & $27.8 \pm 14.40$ & $23 \pm 12.26$ \\
\hline & & $(p=0.314)$ & $(p=0.018)$ & $(p=0.008)$ \\
\hline
\end{tabular}

\section{Discussion}

The association of propofol with other anesthetic agents for induction tends to reduce its necessary dose for intubation, and therefore reduces the possibility of adverse effects (LERCHE et al., 2000; SRISVASTAVA et al., 2006; MAIR et al., 2009). The $23.6 \%$ reduction in the dose of the induction agent observed in the present study led to a reduction in occurrence of apnea and adverse effects associated with propofol, such as myoclonic twitching, which occurred in only one dog from the control group. This corroborates the findings of the aforementioned authors.

Although described as a respiration pattern in ketamine anesthesia, apneustic respiration was not observed in the KP group, as was also reported by Mair et al. (2009). On the other hand, Lerche et al. (2000) observed the opposite; there was an increase in the number of animals exhibiting apnea when anesthetized with ketamine-propofol association, and in the time to first spontaneous breath. The latter authors suggest that this may be a consequence of the empirically chosen higher dose of ketamine $\left(2 \mathrm{mg} \mathrm{kg}^{-1}\right)$ used, which may have aggravated the respiratory depression caused by propofol. Additionally, these authors reported the occurrence of apneustic respiration, nevertheless it was observed in both groups (propofol only and ketamine-propofol). According to the authors, although it is more commonly associated with ketamine, it may also be a consequence of general anesthesia itself.

Regarding intubation quality, it has been reported that ketamine promotes increased reflex in the respiratory tract, which hampers intubation (GUPTA et al., 2011). Nevertheless, this was not observed in the present study, in which intubation quality was better in the group anesthetized with ketamine-propofol than with propofol alone. 
When comparing vital parameters between groups, there were, in fact, differences. Although all patients showed a reduction in vital parameters after induction of anesthesia, patients in the KP group had greater or similar values, when compared to patients in the $\mathrm{P}$ group. The lower values obtained for the $\mathrm{P}$ group show a greater risk of bradycardia, bradypnea or apnea, and hypotension. Lerche et al. (2000) reported the same result regarding heart rate. Patients that were administered ketamine-propofol had greater heart rate values, a result attributed to the stimulatory effects of ketamine, which may have inhibited or reduced the depressing effects of propofol. The higher arterial blood pressure obtained for the KP group compared to the $\mathrm{P}$ group, corroborate the findings of other studies on humans anesthetized with ketamine-propofol (HUI et al., 1995; SRIVASTAVA et al., 2006).

Two linear models were applied for each vital parameter, in order to statistically infer the likelihood that an increase in the dose of the drugs used would influence these parameters. One model implied that the decrease in these values was dose-dependent, while the other implied it was independent of the dose used. Following the application of these models, a Chisquare test was done to estimate the probability of this occurrence. According to this analysis, vital parameters, especially arterial blood pressure, were not dose-dependent in the KP group (i.e. there are no changes in vital parameters when there is an increase in drug dose). On the other hand, in the $\mathrm{P}$ group, arterial blood pressure is greatly affected by an increase in the dose of propofol, which leads to hypotension. Therefore, the association of ketamine, when using higher doses of propofol, significantly reduces the probability of hypotension, yielding a safer procedure with less side effects. This corroborates the hypotheses that ketamine inhibits the depressing effects on the cardiovascular system, caused by the use of propofol (MAIR et al., 2009).

In conclusion, induction of anesthesia with the association of propofol and $1 \mathrm{mg} \mathrm{kg}^{-1}$ of ketamine significantly reduced the necessary dose of the induction agent for endotracheal intubation. It also allowed for a good quality intubation, less adverse effects, and greater cardiopulmonary stability for the patients, with lesser occurrence of bradypnea, apnea, bradycardia, and hypotension when compared to propofol alone. Therefore, ketamine is a good adjuvant to propofol for induction of hemodynamically stable and healthy dogs, yielding greater safety during anesthesia.

\section{Acknowledgements}

The authors wish to thank André Baceti, Fabiola Maiumi Oshiro Monreal and Pedro Ivo Miguel Avelino for the statistics analysis and the Veterinary Hospital of Paulista University for allowing the research. 


\section{References}

ANDREONI, V.; LYNNE HUGHES, J. Propofol and fentanyl infusions in dogs of various breeds undergoing surgery. Veterinary Anaesthesia and Analgesia, v. 36, n. 6, p. 523-531, 2009. doi: http://dx.doi.org/10.1111/j.14672995.2009.00490.x.

COVEY-CRUMP, G. L.; MURISON, P. J. Fentanyl or midazolam for co-induction of anaesthesia with propofol in dogs. Veterinary Anaesthesia and Analgesia, v. 35, n. 6, p. 463-472, 2008. doi: http://dx.doiorg/10.1111/j.1467-2995.2008.00408x.

DAVIES, C. Excitatory phenomena following the use of propofol in dogs. Veterinary Anaesthesia and Analgesia, v. 18, n. 1, p. 48-51, 1991. doi: http://dx.doi.org/10.1111/j.14672995.1991.tb00014.x.

FURUYA, A.; MATSUKAWA, T.; OZAKI, M.; NISHIYAMA, T.; KUME, M.; KUMAZAWA, T. Intravenous ketamine attenuates arterial pressure changes during the induction of anaesthesia with propofol. European Journal of Anaesthesiology, v. 18, n. 2, p. 88-92, 2001. doi: http://dx.doi.org/10.1046/j.0265-0215.2000.00784.x.

GUPTA, A.; KAUR, S.; ATTRI, J. P.; SAINI, N. Comparative evaluation of ketamine-propofol, fentanyl-propofol and butorphanol-propofol on haemodynamics and laryngeal mask airway insertion conditions. Journal of Anaesthesiology Clinical Pharmacology, v. 27, n. 1, p. 7478, 2011.

HASKINS, S. C.; FARVER, T. B.; PATZ, J. D. Ketamine in dogs. American Journal of Veterinary Research, v. 46, n. 9, p. 1855-1860, 1985.

HUI, T. W.; SHORT, T. G.; HONG, W.; SUEN, T.; GIN, T.; PLUMMER, J. Additive interactions between propofol and ketamine when used for anesthesia induction in female patients. Anesthesiology, v. 82, n. 3, p. 641-648, 1995.

INTELISANO, T. R.; KITAHARA, F. R.; OTSUKI, D. A.; FANTONI, D. T.; AULER JUNIOR, J. O. C.; CORTOPASSI, S. R. G. Total intravenous anaesthesia with propofol-racemic ketamine and propofol-S-ketamine: a comparative study and haemodynamic evaluation in dogs undergoing ovariohysterectomy. Pesquisa Veterinária Brasileira, v. 28, n. 4, p. 216-222, 2008. doi: http://dx.doi.org/10.1590/S0100736 X2008000400004.
LAFLAMME, D. Development and validation of a body condition score system for dogs. Canine Practice, v. 22, n. 4, p. 10-15, 1997.

LERCHE, P.; REID, J.; NOLAN, A. M. Comparative study of propofol or propofol and ketamine for induction of anaesthesia in dogs. Veterinary Record, v. 146, n. 20, p. 571574, 2000. doi: http://dx.doi.org/10.1136/vr.146.20.571.

MAIR, A. R.; PAWSON, P.; COURCIER, E.; FLAHERTY, D. A comparison of the effects of two different doses of ketamine used for co-induction of anaesthesia with a targetcontrolled infusion of propofol in dogs. Veterinary Anaesthesia and Analgesia, v. 36, n. 6, p. 532-538, 2009. doi: http://dx.doi.org/10.1111/j.1467-2995.2009.00500.x.

MAWBY, D. I.; BARTGES, J. W.; MOYERS, T.; COTTRELL, T.; LAFLAMME, D. P. Comparison of body fat estimates by dual-energy X-ray absorptiometry and deuterium oxide dilution in client owned dogs. Compendium, v. 23, n. 9A, p. 70, 2001.

MAYER, M. L.; MILLER, R. J. Excitatory amino acid receptors, second messengers and regulation of intracellular $\mathrm{Ca}^{2+}$ in mammalian neurons. Trends in Pharmacological Sciences, v. 11, n. 6, p. 254-260, 1990 . doi: http://dx.doi.org/10.1016/0165-6147(90)90254-6.

ROYTBLAT, L.; KOROTKORUCHKO, A.; KATZ, J.; GLAZER, M.; GREEMBERG, L.; FISHER, A. Postoperative pain: the effect of low dose ketamine in addition to general anesthesia. Anesthesia \& Analgesia, v. 77, n. 6, p. 1161-1165, 1993. doi: http://dx.doi.org/10.1213/00000539-199312000-00014.

SMITH, J. A.; GAYNOR, J. S.; BEDNARSKI, R.; MUIR, W. W. Adverse effects of administration of propofol with various preanaesthetic regimens in dogs. Journal of the American Veterinary Medical Association, v. 202, n. 7, p. 1111-1115, 1993.

SRIVASTAVA, U.; SHARMA, N.; KUMAR, A.; SAXENA, S. Small dose propofol or ketamine as an alternative to midazolam co-induction to propofol. Indian Journal of Anaesthesia, v. 50, n. 2, p. 112-114, 2006.

WRIGHT, M. Pharmacology effects of ketamine and its use in veterinary medicine. Journal of the American Veterinary Medical Association, v. 180, n. 12, p. 1462$1471,1982$. 